\title{
Selection of entomopathogenic nematodes and evaluation of their compatibility with cyantraniliprole for the control of Hypothenemus hampei
}

\author{
Seleção de nematoides entomopatogênicos e avaliação da sua \\ compatibilidade com ciantraniliprole visando o controle de \\ Hypothenemus hampei
}

\author{
Bruna Aparecida Guide ${ }^{1 *}$; Viviane Sandra Alves ${ }^{2}$; Thiago Augusto Paes Fernandes \\ Matheus Corseti Marcomini ${ }^{4}$; Ana Maria Meneguim ${ }^{5}$; \\ Pedro Manuel Oliveira Janeiro Neves ${ }^{6}$
}

\begin{abstract}
Attack by the coffee berry borer Hypothenemus hampei causes significant damage to coffee crops because it affects the quality of the coffee fruit during different developmental stages, which results in production losses. Control of the borer is difficult owing to its cryptic behavior and the fact that it spends its entire life cycle inside the coffee berries. This makes it difficult for natural enemies to reach it, as well as for it to come into contact with chemical insecticides. The objective of the present study was to select and evaluate the virulence of entomopathogenic nematodes (EPNs) on the coffee berry borer $H$. hampei and their compatibility with the insecticide cyantraniliprole under laboratory conditions. Initially, the pathogenicity and virulence of 16 isolates of Steinernema and Heterorhabditis towards coffee berry borer larvae and adults were evaluated. The most virulent isolates to both larvae and adults were determined by topical inoculation tests in coffee fruits (berries) infested by the insect, using a concentration of 100 infective juveniles (IJs)/fruit. The same isolates were also evaluated for viability and infectivity when combined with cyantraniliprole. The isolates $S$. feltiae (IBCB-n 47) and Heterorhabditis amazonensis (GL) displayed the highest virulence towards adults (54\%). For larvae, we observed a high virulence of $S$. feltiae, Heterorhabditis amazonensis, Heterorhabditis indica, Heterorhabditis sp. (JPM4), Heterorhabditis sp. (NEPET 11), Heterorhabditis sp. (IBCB-n 46), and Heterorhabditis sp. (IBCB-n 44) that promoted 100\% mortality. Regarding the topical inoculation test on infested fruits, S. feltiae and Heterorhabditis sp. (IBCB-n 46) were unable to penetrate the fruit through the hole made by the borer, infect, and cause the death of insects. Cyantraniliprole formulation affected the viability of IJs of $S$. feltiae and Heterorhabditis sp. (IBCB-n 46), mainly after $48 \mathrm{~h}$ of exposure.
\end{abstract}

Key words: Biological control. Heterorhabditis. Steinernema. Coffea arabica. Coffea canephora.

1 Bióloga, Discente, Curso de Doutorado, Programa de Pós-Graduação em Agronomia, Universidade Estadual de Londrina, UEL, Londrina, PR, Brasil. E-mail: bruhguide@gmail.com

2 Bióloga, Prof ${ }^{\mathrm{a}} \mathrm{Dr}^{\mathrm{a}}$, Departamento de Biologia, Universidade Estadual do Norte do Paraná, UENP, Cornélio Procópio, PR, Brasil. E-mail: vivialves@uenp.edu.br

3 Biólogo, Discente, Curso de Mestrado, Programa de Pós-Graduação em Agronomia, UEL, Londrina, PR, Brasil. E-mail: thiagouenp@gmail.com

4 Discente, Curso de Graduação em Agronomia, UEL, Londrina, PR, Brasil. E-mail: matheusmarcomini11@outlook.com

5 Eng $^{\mathrm{a}}$ Agr $^{\mathrm{a}}$, Dr ${ }^{\mathrm{a}}$., Pesquisadora, Instituto Agronômico do Paraná, IAPAR, Londrina, PR, Brasil. E-mail: meneguim@iapar.br

6 Eng $^{\circ}$ Agr ${ }^{\circ}$, Prof. Dr., Departamento de Agronomia, UEL, Londrina, PR, Brasil. E-mail: pedroneves@uel.br

"Author for correspondence

Received: Dec. 14, 2017 - Approved: May 30, 2018 


\title{
Resumo
}

\begin{abstract}
A broca-do-café Hypothenemus hampei causa significativos prejuízos a esta cultura, pois seu ataque afeta a qualidade dos frutos de café em seus diferentes estádios de desenvolvimento e consequentemente leva a perdas na produção. O controle é dificultado devido ao seu comportamento críptico, uma vez que passa todo o ciclo dentro dos frutos de café, dificultando a ação de inimigos naturais, bem como o contato com inseticidas químicos. O objetivo deste estudo foi avaliar a virulência de nematoides entomopatogênicos (NEPs) sobre a broca-do-café $H$. hampei e a sua compatibilidade com o inseticida ciantraniliprole em condições de laboratório. Inicialmente, foram avaliadas a patogenicidade e virulência de 16 isolados de Steinernema e Heterorhabditis para larvas e adultos de H. hampei. Os isolados mais virulentos para larvas e adultos foram utilizados no teste de inoculação tópica em frutos de café infestados pelo inseto, utilizando uma concentração de 100 juvenis infectantes (JIs)/fruto. Os mesmos isolados também foram avaliados quanto à viabilidade e à infectividade quando combinados com ciantraniliprole. Os isolados Steinernema feltiae (IBCB-n 47) e Heterorhabditis amazonensis (GL) foram os que apresentaram maior porcentagem de mortalidade sobre os adultos (54\%). Para larvas, observou-se alta virulência dos isolados S. feltiae, H. amazonensis, H. indica, Heterorhabditis sp. (JPM4), Heterorhabditis sp. (NEPET11), Heterorhabditis sp. (IBCB-n 46) e Heterorhabditis sp. (IBCB-n 44) que promoveram $100 \%$ de mortalidade. Quanto ao teste de inoculação tópica sobre frutos infestados, observou-se que tanto S. feltiae quanto Heterorhabditis sp. (IBCB-n 46) não foram capazes de penetrar o fruto pelo orifício feito pela broca, infectar e causar a morte dos insetos. A formulação de ciantraniliprole afetou a viabilidade dos JIs de S. feltiae e Heterorhabditis sp. (IBCB-n 46), principalmente após 48 horas de exposição.
\end{abstract}

Palavras-chave: Controle biológico. Heterorhabditis. Steinernema. Coffea arabica. Coffea canephora.

\section{Introduction}

The coffee berry borer, Hypothenemus hampei (Ferrari) (Coleoptera: Curculionidae) is considered one of the most important coffee pests. It is found in almost all coffee producing regions and directly attacks the fruit of the coffee on which it feeds, develops, and reproduces. The damage can be seen in all stages of maturation and is characterized by weight loss and depreciation of the grain (VEGA et al., 2009). In addition, attacks may facilitate the entry of microorganisms that develop in grains, affecting the quality of the final coffee product (VEGA et al., 2009, 2014). The annual losses caused by this insect in Brazil have already exceeded US\$300 million (OLIVEIRA et al., 2013).

The methods used to control this insect are based on the use of synthetic insecticides (JARAMILLO et al., 2011); however, alternative controls are required. Previous studies on the use of biological controls have been performed, such as the use of plant extracts of Tephrosia purpurea (leaf) and Moringa oleifera (seed) that showed lethal activity against H.hampei (ZORZETTI et al., 2012). The use of parasitoids of the family Bethylidae has also been evaluated; however, results have not been promising, because of the difficulty in breeding, mass production, adaptation, and non-significant levels of parasitism (VEGA et al., 2009). Entomopathogenic fungi such as Beauveria bassiana are also important control agents of adults (MOTA et al., 2017); however, they need ideal conditions to remain viable in the environment, which hampers their use (NEVES; HIROSE, 2005).

Insect control with entomopathogenic nematodes (EPNs) can be a viable, efficient, and safe alternative. These entomopathogens possess several characteristics, such as the ability to search the host and compatibility with plant protection products that make them advantageous compared to other biological control agents (LEWIS et al., 2006). In addition, studies have demonstrated that EPNs are able to penetrate the coffee fruit that have fallen on the ground through the orifice made by the drill, thus presenting good results in the control of $H$. 
hampei (MOLINA; LÓPEZ, 2009; BENAVIDESMACHADO et al., 2010; MANTON et al., 2012).

Within the groups of EPNs considered important in pest control, the genus Heterorhabditis Poinar, 1976 and Steinernema Travassos, 1927 stand out because they are known for aspects related to ecology, pest action strategies, large-scale production, and application conditions.

Given that infested coffee fruits that have fallen on the ground and those left on the plant after harvesting are the main sources of reinfestation during the next harvest (BENAVIDES-MACHADO et al., 2010) and the difficulty in controlling this pest due to its cryptic habit, the use of EPNs may be a promising alternative to traditional methods.

Thus, the objective of the present study was to assess the potential use of EPNs as an alternative for biological control of the coffee berry borer, $H$. hampei, and the compatibility of these agents with the insecticide cyantraniliprole.

\section{Materials and Methods}

Experiments were carried out under laboratory conditions. The coffee borer was obtained from the Laboratory of Entomology of the Agronomic Institute of Paraná and was maintained in a climatic chamber $\left(25 \pm 2{ }^{\circ} \mathrm{C}\right.$, relative humidity (RH): $60 \pm$ $10 \%$, no light) and developed on an artificial diet adapted from Villacorta and Barrera (1993), with the following modifications: $150 \mathrm{~g}$ of coffee powder (raw grain) and $0.5 \mathrm{~g}$ of Vanderzant vitamin mixture for insects were added.

\section{Obtaining and maintaining isolates of entomopathogenic nematodes}

Sixteen isolates of EPNs were obtained from the database of entomopathogens from the Laboratory of Entomology and Microbial Control of the State University of North Paraná (Cornélio Procópio, PR) and the Biological Institute (Campinas, SP) (Table 1).

Table 1. Isolates of entomopathogenic nematodes of the genera Steinernema and Heterorhabditis used in the selection test against larvae and adults of Hypothenemus hampei under laboratory conditions.

\begin{tabular}{ccc}
\hline Species & Isolate & Origin \\
\hline Heterorhabditis amazonensis & RSC 05 & Benjamin Constant, AM, Brazil \\
Heterorhabditis indica & IBCB-n 05 & Itapetininga, SP, Brazil \\
Heterorhabditis bacteriophora & HP 88 & New Jersey, USA \\
Heterorhabditis sp. & NEPET 11 & Palmeira das Missões, RS, Brazil \\
Heterorhabditis amazonensis & GL & Lavras, MG, Brazil \\
Heterorhabditis sp. & JPM 4 & Lavras, MG, Brazil \\
Heterorhabditis sp. & IBCB-n 40 & Taboporã, SP, Brazil \\
Heterorhabditis sp. & IBCB-n 46 & Santo Antônio de Posse, SP, Brazil \\
Heterorhabditis sp. & IBCB-n 44 & Santa Adélia, SP, Brazil \\
Steinernema sp. & IBCB-n 27 & Mogi Guaçu, SP, Brazil \\
Steinernema carpocapsae & IBCB-n 02 & Flórida, USA \\
Steinernema diaprepesi & AM 163 & Sinop, MT, Brazil \\
Steinernema rarum & PAM & Aceguá, RS, Brazil \\
Steinernema feltiae & IBCB-n 47 & Flórida, USA \\
Steinernema puertoricense & CER-n 125 & Rio Verde, GO, Brazil \\
Steinernema glaseri & IBCB-n 01 & Botucatu, SP, Brazil \\
\hline
\end{tabular}


Breeding was performed with the in vivo method adapted from the methodology described by Molina and López (2001), using the last instar larvae of Galleria mellonella (Linnaeus) (Lepidoptera: Pyralidae) from established breeders. After the emergence of the infective juveniles (IJs), they were collected and placed in distilled water, stored in plastic pots, and maintained in a climatic chamber at $18 \pm 1{ }^{\circ} \mathrm{C}$ without photoperiod for up to 3 days.

Virulence of entomopathogenic nematodes against H. hampei adults

Each isolate (treatment) was replicated five times. The experimental unit corresponded to a $5.5 \mathrm{~cm}$ diameter glass Petri dish containing one unsexed insect and two dry filter paper sheets on the base and plate lid. The isolates were then applied at a concentration of $100 \mathrm{IJs} / \mathrm{cm}^{2}$ on the base and lid papers of the dish with the aid of a micropipette.

After application, the dishes were capped, sealed with plastic film, and maintained in a climatic chamber at $25 \pm 1{ }^{\circ} \mathrm{C}$, RH: $70 \pm 10 \%$, and in scotophase. An additional treatment (control) was included, which contained only $1 \mathrm{~mL}$ of distilled water. Evaluation occurred 5 days after inoculation and quantified the number of insects killed by the nematodes. To confirm mortality, the insects were dissected and displacement of the head from the thorax was recorded.

The experiment was designed in a randomized experimental design. The data were subjected to analysis of variance, transformed into $\operatorname{root}^{2}(x+0.5)$ to meet the assumptions of a parametric analysis, and the means were compared by the Scott-Knott test with 5\% significance using the SISVAR 5.4 software program (FERREIRA, 2011).

Virulence of entomopathogenic nematodes against H. hampei larvae

The treatments consisted of four replications.
Each replication corresponded to a Petri dish of $5.5 \mathrm{~cm}$ in diameter, containing ten second instar larvae, two filter papers in the base, and the diet (the same as that used for breeding). Then, for each isolate, $1 \mathrm{~mL}$ of suspension containing the isolate at a concentration of $100 \mathrm{IJs} / \mathrm{cm}^{2}$ was applied on the filter papers with the aid of a micropipette.

After inoculation, the plates were capped and maintained in a climatic chamber at $25 \pm 1^{\circ} \mathrm{C}$, RH: $70 \pm 10 \%$, and without photophase. An additional treatment (control) was included that only received $1 \mathrm{~mL}$ of distilled water. Evaluation occurred 5 days after inoculation and quantified the number of dead larvae.

The experiment was designed in a randomized experimental design. The statistical procedure performed with the data from the screening test with larvae of the coffee berry borer was the same as that for the adults. However, the processing of data was not necessary.

Application of infective juveniles on infested coffee fruits

In the present study, the isolates $S$. feltiae (IBCB-n 47) and Heterorhabditis sp. (IBCB-n 46), which were among the most virulent of the selection tested, were used.

The following treatments were performed: nematode isolates applied in aqueous suspension; nematode isolates applied with $0.5 \%$ xanthan gum fixative to avoid dehydration; and the control treatment, in which only distilled water was applied. Each treatment consisted of eight replicates and the experimental unit was a $9 \mathrm{~cm}$ diameter glass Petri dish containing $10 \mathrm{~g}$ of previously autoclaved and $80{ }^{\circ} \mathrm{C}$ oven-dried vermiculite as the base for the fruit and two infested fruits. A total of 100 IJs were applied on each fruit with the help of a micropipette. The plates were capped and maintained in a climatic chamber at $25 \pm 1{ }^{\circ} \mathrm{C}$ and without photophase for 5 days. 
To evaluate the mortality of insects, the fruits were washed superficially with distilled water to eliminate the EPNs that had not yet penetrated. Then, dissection of the fruits occurred. The numbers of IJs inside the fruits, apart from eggs, and all stages of the insect (e.g., larva, pupa, and adult) were counted, and the dead drills dissected with the aid of a stereoscope microscope to confirm parasitism by EPNs.

\section{Compatibility of EPNs isolates with cyantraniliprole}

The assessment of the compatibility of S. feltiae (IBCB-n 47) and Heterorhabditis sp. (IBCB-n 46) with the insecticide cyantraniliprole was performed based on the methodology described by Vainio (1992) and modified by Negrisoli Júnior et al. (2008).

One liter of product formulation was prepared with twice the recommended dose of cyantraniliprole (1,750 $\mathrm{mL}$ of commercial product/400 L of water). Thus, $8.75 \mathrm{~mL}$ of commercial product were added to $1,000 \mathrm{~mL}$ of water. A $1 \mathrm{~mL}$ sample of this solution was distributed in five glass tubes per treatment. A sample of $1 \mathrm{~mL}$ of distilled water containing 2,500 IJs was added to each tube, thus re-establishing the dose recommended for field application. As a control, $1 \mathrm{~mL}$ of suspension of isolates was mixed with $1 \mathrm{~mL}$ of distilled water. The tubes were stored in a climatic chamber at $22 \pm 1{ }^{\circ} \mathrm{C}, \mathrm{RH}$ of $70 \pm 10 \%$, and without photophase.

The viability of nematodes was evaluated at $24 \mathrm{~h}$ and $48 \mathrm{~h}$ after exposure to the product. Thus, $50 \mu \mathrm{L}$ of the suspension in each tube (replicate) was removed and $100 \mathrm{IJs}$ were observed under a stereoscope microscope to determine viability. All immobile nematodes and those that did not respond to touch with a stylus were considered dead and those who displayed movement were considered alive.
The infectivity of IJs was evaluated during the same period as viability. The tubes were supplemented with $3 \mathrm{~mL}$ of distilled water and left to settle for $30 \mathrm{~min}$ in a fridge at $10^{\circ} \mathrm{C}$, after which the supernatant (approximately $3 \mathrm{~mL}$ ) was discarded. This rinsing procedure was repeated three times to remove the maximum amount of insecticide. After the last wash, $1 \mathrm{~mL}$ (approximately 1,000 IJs) was removed from the bottom of each tube and applied on five Petri plates containing two filter papers and ten last instar larvae of G. mellonella.

The plates were maintained in a climatic chamber at $22 \pm 1^{\circ} \mathrm{C}$ for 5 days. After this period, the dead larvae were transferred to plates containing a dry filter paper and maintained in the dark for over $72 \mathrm{~h}$, and were then dissected with the aid of a stereoscope microscope to confirm death by nematodes.

The viability of nematodes after exposure to cyantraniliprole and mortality of larvae infected by EPNs were submitted to analysis of variance and the means were compared by the Tukey's test ( $P$ $\leq 0.05$ ) using the SISVAR 5.4 software program (FERREIRA, 2011).

\section{Results and Discussion}

\section{Selection test with adults}

All isolates were pathogenic; however, they displayed differences in virulence. Mortality ranged from $2 \%$ to $54 \%$ (Table 2).

The difference in virulence among isolates, even of the same species, can be justified by several factors. Different isolates can be adapted to different climatic conditions or develop host specificity (ALVES et al., 2009). According to a study by Almenara et al. (2012), such variation in susceptibility is expected because different isolates coevolved with different host species and, therefore, have characteristics that make them virulent to a greater or lesser degree on certain insects. 
Table 2. Mortality (\%) of adults of Hypothenemus hampei caused by entomopathogenic nematodes (Steinernema spp. and Heterorhabditis spp.) under laboratory conditions $\left(25 \pm 1{ }^{\circ} \mathrm{C}\right.$, RH $70 \pm 10 \%$, and without photophase).

\begin{tabular}{ccc}
\hline Species & Isolate & Mortality $(\%) \pm($ SEM) \\
\hline Steinernema feltiae & IBCB-n 47 & $54.0 \pm 8.1 \mathrm{a} *$ \\
Heterorhabditis amazonensis & GL & $54.0 \pm 7.5 \mathrm{a}$ \\
Heterorhabditis sp. & IBCB-n 46 & $50.0 \pm 7.1 \mathrm{a}$ \\
Heterorhabditis bacteriophora & HP 88 & $46.0 \pm 9.8 \mathrm{a}$ \\
Heterorhabditis indica & IBCB-n 05 & $44.0 \pm 13.6 \mathrm{a}$ \\
Steinernema diaprepesi & AM 163 & $44.0 \pm 9.8 \mathrm{a}$ \\
Steinernema glaseri & IBCB-n 01 & $42.0 \pm 7.3 \mathrm{a}$ \\
Heterorhabditis sp. & IBCB-n 40 & $40.0 \pm 7.1 \mathrm{a}$ \\
Heterorhabditis sp. & IBCB-n 44 & $40.0 \pm 8.4 \mathrm{a}$ \\
Steinernema rarum & PAM & $38.0 \pm 6.6 \mathrm{a}$ \\
Heterorhabditis amazonensis & RSC 05 & $24.0 \pm 7.5 \mathrm{~b}$ \\
Heterorhabditis sp. & JPM 4 & $22.0 \pm 5.8 \mathrm{~b}$ \\
Steinernema carpocapsae & IBCB-n 02 & $22.0 \pm 7.3 \mathrm{~b}$ \\
Heterorhabditis sp. & NEPET 11 & $16.0 \pm 6.0 \mathrm{c}$ \\
Steinernema sp. & IBCB-n 27 & $6.0 \pm 4.0 \mathrm{~d}$ \\
Steinernema puertoricense & CER-n 125 & $4.0 \pm 2.4 \mathrm{~d}$ \\
Control & - & $2.0 \pm 2.0 \mathrm{~d}$ \\
\hline
\end{tabular}

*Means followed by the same letter do not differ by the Skott-Knott test $(\mathrm{p} \leq 5 \%)$ with data transformed into $\operatorname{root}^{2}(\mathrm{x}+0.5)$.

From a previous study (CASTILLO; MARBÁNMENDOZA, 1996) that assessed the pathogenicity of eight isolates of EPNs on coffee berry borer adults in Petri plates containing diet, the isolates Heterorhabditis LIM-1, DOM-8, and PC-3, and the commercial isolate $S$. carpocapsae (Biosys) were found to be the most virulent to insects, with a mortality percentage above $50 \%$. In the present study, a similar mortality percentage was observed for some of the Heterorhabditis isolates; however, S. carpocapsae caused lower mortality (22\%) than that observed by the authors.

Benavides-Machado et al. (2010) evaluated the virulence of isolates of nematodes on coffee berry borer adults and observed that all treatments were pathogenic to the insects, whereas the mortality 5 days after the application ranged from 3.6\% to $24.6 \%$, with $H$. bacteriophora being the most virulent isolate $(24.6 \%)$. These results are lower than those found in the present study because $H$. bacteriophora caused $46 \%$ mortality in insects (Table 2).

It was also observed that, in general, the isolates of the genus Heterorhabditis were more virulent to adults of $H$. hampei. Identical results were observed by Castillo and Marbán-Mendoza (1996) and Benavides-Machado et al. (2010) in studies conducted with coffee berry borer adults.

Sepúlveda-Cano et al. (2008) performed tests with Cosmopolites sordidus (Coleoptera: Curculionidae) adults and observed higher mortality with $H$. bacteriophora (58\%) than with $S$. carpocapsae $(40 \%)$, which shows some similarity with the present study where $S$. carpocapsae was less virulent to adults of the coffee berry borer compared to H. bacteriophora $(22.0 \%$ and $46.0 \%$, respectively). 
In previous studies by Tavares et al. (2007) and Giometti et al. (2011), Heterorhabditis isolates displayed higher virulence that Steinernema on sugarcane weevil adults, Sphenophorus levis (Coleoptera: Curculionidae).

Other studies carried out under similar conditions evidenced the susceptibility of curculionids to the nematodes of the genus Steinernema, but preferentially to isolates of the genus Heterorhabditis (SHAPIRO-ILAN et al., 2000; STUART et al., 2004, SEPÚLVEDA-CANO et al., 2008). The higher susceptibility to Heterorhabditis can be explained in part by the fact that they have small appendages in the cephalic region that allow them to penetrate the insect by rupturing their integument (GEDEN et al., 1985).

Adults of $H$. hampei infected by EPNs did not present the typical staining of infection for either nematode genus and some infected adults had displacement of the head from the thorax. This latter feature was also observed by Benavides-Machado et al. (2010) who emphasized the fact that the cause of this displacement is probably due to the pressure generated by the nematode during its development inside the insect.

\section{Selection test with larvae}

All isolates were pathogenic to larvae of $H$. hampei, however, the virulence varied. The mortality ranged from $15 \%$ to $100 \%$. It was also observed that twelve isolates caused mortality above $80 \%$, and seven of these (six of the genus Heterorhabditis and one of the genus Steinernema) were able to kill $100 \%$ of the larvae (Table 3 ).

Table 3. Mortality (\%) of larvae of Hypothenemus hampei caused by entomopathogenic nematodes (Steinernema spp. and Heterorhabditis spp.) under laboratory conditions $\left(25 \pm 1{ }^{\circ} \mathrm{C}\right.$, RH: $70 \pm 10 \%$, and without photophase).

\begin{tabular}{|c|c|c|}
\hline Species & Isolate & Mortality $(\%) \pm($ SEM $)$ \\
\hline Heterorhabditis indica & IBCB-n 05 & $100.0 \pm 0.0 \mathrm{a}^{*}$ \\
\hline Heterorhabditis sp. & JPM 4 & $100.0 \pm 0.0 \mathrm{a}$ \\
\hline Heterorhabditis sp. & NEPET 11 & $100.0 \pm 0.0 \mathrm{a}$ \\
\hline Heterorhabditis sp. & IBCB-n 44 & $100.0 \pm 0.0 \mathrm{a}$ \\
\hline Heterorhabditis sp. & IBCB-n 46 & $100.0 \pm 0.0 \mathrm{a}$ \\
\hline Heterorhabditis amazonensis & RSC 05 & $100.0 \pm 0.0 \mathrm{a}$ \\
\hline Steinernema feltiae & IBCB-n 47 & $100.0 \pm 0.0 \mathrm{a}$ \\
\hline Heterorhabditis amazonensis & GL & $97.0 \pm 2.5 \mathrm{a}$ \\
\hline Steinernema rarum & PAM & $90.0 \pm 5.8 \mathrm{~b}$ \\
\hline Heterorhabditis sp. & IBCB-n 40 & $87.5 \pm 6.3 b$ \\
\hline Steinernema carpocapsae & IBCB-n 02 & $87.5 \pm 2.5 b$ \\
\hline Steinernema sp. & IBCB-n 27 & $85.0 \pm 2.9 \mathrm{~b}$ \\
\hline Heterorhabditis bacteriophora & HP88 & $70.0 \pm 10.0 \mathrm{~b}$ \\
\hline Steinernema glaseri & IBCB-n 01 & $35.0 \pm 5.0 \mathrm{c}$ \\
\hline Steinernema diaprepesi & AM 163 & $32.0 \pm 2.5 \mathrm{c}$ \\
\hline Steinernema puertoricense & CER-n 125 & $15.0 \pm 5.0 \mathrm{~d}$ \\
\hline \multirow[t]{2}{*}{ Control } & - & $5.0 \pm 2.9 \mathrm{~d}$ \\
\hline & & $\mathrm{CV}(\%)=10.12$ \\
\hline
\end{tabular}

* Means followed by the same letter did not differ by the Scott-Knott test ( $\mathrm{p} \leq 5 \%)$. 
When evaluating the virulence of EPNs on larvae of the coffee berry borer, Benavides-Machado et al. (2010) observed that all isolates were pathogenic and species of the genus Steinernema caused mortality between $75 \%$ and $90 \%$, whereas those of the genus Heterorhabditis caused between $36.5 \%$ and $42 \%$ mortality. These data differ from the values observed in the present study, as for the genus Steinernema, the mortality ranged between $15 \%$ and $100 \%$ and for Heterorhabditis mortality ranged between $70 \%$ and $100 \%$.

The H. hampei larvae were more susceptible to nematodes than the adults were, reinforcing a trend of higher susceptibility to EPNs that has been verified previously for coffee berry borer larvae (MOLINA; LÓPEZ, 2009; BENAVIDES-MACHADO et al., 2010) and several other coleopterans of the family Curculionidae in laboratory tests (SHAPIRO-ILAN et al., 2000, 2003; DUNCAN et al., 2003; STUART et al., 2004).

The variations in the susceptibility of different stages (larvae and adults) of H. hampei can be explained by differences in morphology and behavior. The larvae have a less rigid cuticle, more exposed spiracles, and less mobility, which favors the entrance of the infecting juveniles, unlike the adults of $H$. hampei that present a more rigid cuticle, small spiracles hidden under the elytra, and large mandibles (BENAVIDES- MACHADO et al., 2010). All these factors contribute to low mortality, making the adult stage of the coffee borer less susceptible to attack by EPNs.

It was possible to observe the complete development of nematodes during the larval stage of H. hampei and decomposition of the larvae tissues. Moreover, the typical symptoms of infection by isolates of the genus Steinernema, in which the larvae begin to present a yellowish coloration, were observed, as well as typical symptoms of infection by isolates of the genus Heterorhabditis, i.e., the infected larvae showed a reddish staining because of the proliferation of bacteria that change the color of the insect (VOSS, 2009). These symptoms of infection were also observed in previous studies (MOLINA; LOPES, 2009; BENAVIDESMACHADO et al., 2010).

\section{Application of infective juveniles on infested coffee fruit}

Both S. feltiae and Heterorhabditis sp. (IBCB-n 46) applied in aqueous suspension and with xanthan gum were unable to penetrate the fruit through the orifice made by the drill, infect, and cause the death of insects inside the fruit. No IJs were observed in the galleries made by the drills and no insect showed any symptom of infection by the nematodes. However, 5 days after the application of the EPNs, the presence of some IJs was observed on the fruit and these still had some mobility, which was also observed by Molina and López (2009).

Similar tests have been performed previously under laboratory conditions with eight EPNs isolates, five of the genus Steinernema, and three of the genus Heterorhabditis, and after six days of application none of the isolates caused mortality of the insects inside the fruits, which is in agreement with the observations in the present study (CASTILLO; MARBÁN-MENDOZA, 1996).

Furthermore, Allard and Moore (1989) observed that Heterorhabditis sp., applied at a concentration of $240 \mathrm{IJs} /$ per replicate, after 4 days caused $68 \%$ mortality in drill adults in the fruit. Based on this previous study, 47 adults and 6 dissected larvae were infected by the nematode, which was not observed in the present study because the insects were alive inside the fruit.

In the study by Molina and López (2009), 7 days after application of the IJs, the parasitism was proportional to the doses applied on the fruit, with the highest mortalities obtained with the highest doses (125 and $625 \mathrm{IJs} /$ per fruit). At 
concentrations of 125 and $625 \mathrm{IJs} /$ per fruit, the percentages of mortality caused by $S$. feltiae was $42.88 \%$ and $40.58 \%$, and $56.27 \%$ and $61.16 \%$ by $H$. bacteriophora, respectively.

In tests performed under laboratory conditions, Molina and López (2003) observed that the IJs of $H$. bacteriophora showed high displacement capacity inside the fruit, in contrast with the present study, given that Heterorhabditis sp. (IBCBn-46) was not able to move to the interior of the coffee fruit.

Manton et al. (2012) demonstrated that, after 7 days of application, S. carpocapsae was able to penetrate the fruits and cause $26.6 \%$ mortality in adults and $23.7 \%$ mortality in $H$. hampei larvae. According to this study, the $t$-test confirmed that mortality was significantly higher in coffee fruits treated with nematodes.

Heterorhabditis sp. and Steinernema sp. were applied at different doses on fallen fruits in the field and, one month after application, the percentages of mortality for Heterorhabditis sp. ranged from 53.2\% to $82 \%$ and for Steinernema sp. mortality ranged from $71.25 \%$ to $88.19 \%$ (LARA et al., 2004).

The doses used in the studies cited above were higher than those used in the present study and this may have provided a higher likelihood of the nematode encountering the coffee berry borer and, therefore, the penetration and infection of insects inside the fruit. Conversely, according to Gaugler et al. (1994) and Selvan et al. (1993), a minimum number of IJs is necessary to "overcome" the immune system of the insect, colonize, and cause its death; however, when this number is exceeded, i.e., when high concentrations of EPNs are used, intraspecific competition may occur that jeopardizes the survival, development, and reproduction of nematodes, reducing their virulence, and consequently their efficiency.

\section{Compatibility of EPNs isolates with cyantraniliprole}

Regarding the viability of $S$. feltiae and Heterorhabditis sp. (IBCBn-46) after $24 \mathrm{~h}$ and $48 \mathrm{~h}$ of exposure to the plant protection product, there was a difference between the control and the treatment with cyantraniliprole reducing the viability of IJs in these nematodes, particularly after $48 \mathrm{~h}$ of exposure (Table 4).

Although a reduction in viability was observed, the infectivity of $S$. feltiae and Heterorhabditis sp. (IBCB-n 46) after being exposed for $24 \mathrm{~h}$ to cyantraniliprole was $90 \%$ and neither differed from their controls. After $48 \mathrm{~h}$, the infectivity of S. feltiae was $86.0 \%$, not differing from the control, whereas the infectivity of Heterorhabditis sp. (IBCBn-46) was $76.0 \%$, differing from the control (Table 5). These data suggest that the product had a deleterious effect on the survival of IJs.

Koppenhöfer and Fuzy (2008) observed a negative effect of products belonging to the group of anthranilic diamides, a group to which cyantraniliprole belongs, on the viability of EPNs. The authors found that chlorantraniliprole was compatible with the nematode $H$. bacteriophora when exposed to a tank mix and observed that the combination of the nematode with the product led to high mortality of choroidal larvae, indicating an additive or synergism effect between them. 
Table 4. Percentage of viability $(\mathrm{M} \pm \mathrm{SEM})$ of Steinernema feltiae and Heterorhabditis sp. (IBCB-n46) after $24 \mathrm{~h}$ and $48 \mathrm{~h}$ of exposure to the plant protection product cyantraniliprole (protocol IOBC/WPRS), Vainio (1992).

\begin{tabular}{|c|c|c|}
\hline \multirow{2}{*}{ Treatment } & \multicolumn{2}{|c|}{ Viability $^{1}(\%) 24$ hours after exposure } \\
\hline & Steinernema feltiae (IBCBn-47) & Heterorhabditis sp. (IBCBn-46) \\
\hline Control & $80.6 \pm 1.5 \mathrm{a}^{*}$ & $98.6 \pm 0.2 \mathrm{a}$ \\
\hline Cyantraniliprole & $70.4 \pm 1.9 \mathrm{~b}$ & $64.2 \pm 2.0 \mathrm{~b}$ \\
\hline CV (\%) & 3.34 & 4.28 \\
\hline \multirow{2}{*}{ Treatment } & \multicolumn{2}{|c|}{ Viability $^{1}(\%) 48$ hours after exposure } \\
\hline & Steinernema feltiae (IBCBn-47) & Heterorhabditis sp. (IBCBn-46) \\
\hline Control & $68.0 \pm 2.5 \mathrm{a}$ & $98.2 \pm 0.4 \mathrm{a}$ \\
\hline Cyantraniliprole & $55.6 \pm 2.1 \mathrm{~b}$ & $51.4 \pm 2.5 \mathrm{~b}$ \\
\hline CV (\%) & 4.69 & 4.79 \\
\hline
\end{tabular}

${ }^{1}$ Percentage of alive infective juveniles.

*Means followed by the same letter in the column did not differ among themselves by Tukey's test $(\mathrm{p} \leq 5 \%)$.

Table 5. Percentage of infectivity $(\mathrm{M} \pm \mathrm{SEM})$ of Steinernema feltiae and Heterorhabditis sp. (IBCB-n46) in last instar larvae of Galleria mellonella after $24 \mathrm{~h}$ and $48 \mathrm{~h}$ of exposure to the plant protection product cyantraniliprole (protocol IOBC/WPRS), Vainio (1992).

\begin{tabular}{ccc}
\hline \multirow{2}{*}{ Treatment (24 hours) } & \multicolumn{2}{c}{ Infectivity (\%) } \\
\cline { 2 - 3 } & Steinernema feltiae (IBCBn-47) & Heterorhabditis sp. (IBCBn-46) \\
\hline Control (IJs + distilled water) & $86.0 \pm 4.0 \mathrm{a}^{*}$ & $96.0 \pm 2.4 \mathrm{a}$ \\
\hline IJs exposed to cyantraniliprole & $90.0 \pm 3.2 \mathrm{a}$ & $90.0 \pm 5.5 \mathrm{a}$ \\
\hline CV (\%) & 7.19 & 11.53 \\
\hline \multirow{2}{*}{ Treatment (48 hours) } & \multicolumn{3}{c}{ Infectivity (\%) } \\
\cline { 2 - 3 } & Steinernema feltiae (IBCBn-47) & Heterorhabditis sp. (IBCBn-46) \\
\hline Control (IJs + distilled water) & $90.0 \pm 6.3 \mathrm{a}$ * & $96.0 \pm 2.4 \mathrm{a}$ \\
\hline IJs exposed to cyantraniliprole & $86.0 \pm 7.5 \mathrm{a}$ & $76.0 \pm 6.3 \mathrm{~b}$ \\
\hline CV (\%) & 13.45 & 10.7 \\
\hline
\end{tabular}

${ }^{1}$ Mean number of larvae killed by treatment.

*Means followed by the same letter in the column did not differ among themselves by the Tukey's test ( $\mathrm{p} \leq 5 \%$ ).

In a study carried out by Rovesti and Deseö (1990), the compatibility of various phytosanitary products against $H$. bacteriophora, $S$. carpocapsae, and $S$. feltiae was studied and low viability of $H$. bacteriophora was observed after exposure to the fungicides mancozeb and metalaxyl + folpet. However, high infectivity in G. mellonella larvae was observed, which is in agreement with the observations in the present study. The infectivity may be high even with low viability because few or only one infecting juvenile can cause the death of an insect.
In contrast, Bortoluzzi et al. (2013) assessed the compatibility of Heterorhabditis sp. (IBCB-n 40) with the insecticide carbofuran (Furadan $350 \mathrm{FS}^{\circledR}$ ) and observed that the product did not significantly affect the viability of the IJs; however, it caused a $72 \%$ reduction in the infectivity of the EPNs. The same observation was reported by Andaló et al. (2004), in which the insecticide carbofuran did not affect the viability but reduced $50 \%$ of the infectivity in $S$. arenarium IJs. 
Some authors believe that it is this change in infectivity, and not in viability, that is related to the effect of the products on characteristics related to the behavior of the nematode. This could lead to inhibition of movement, dispersion and attraction to the host, and inhibition of reproduction and development, in such a way that even if the nematode is alive, it will not cause death (ROVESTI; DESEÖ, 1990; LAZNIK et al., 2012).

Based on a study by Andaló et al. (2004), some products act as inhibitors of lipid synthesis, which are the main energy sources for the IJs and represent approximately $30 \%$ of their body weight, and it is through these reserves that the EPNs remain alive until they find a new host to parasitize. Thus, cyantraniliprole may not affect the behavior or the lipid reserves of IJs of S. feltiae (IBCB-n 27) and Heterorhabditis sp. (IBCB-n 46).

According to Vainio's protocol (1992), more than $50 \%$ reduction in mortality rates or reduction of infectivity in relation to the control are indicative of incompatibility. Therefore, cyantraniliprole can be considered compatible with the nematodes evaluated in the present study because the reduction in viability as well as infectivity was lower than $50 \%$.

The results obtained enable us to conclude that, apart from isolates $S$. puertoricense (CER-n 125) and Steinernema sp. (IBCB-n 27), all isolates were pathogenic on adults and larvae of $H$. hampei. Steinernema feltiae and Heterorhabditis sp. (IBCB-n 46) were not able to infect adults and larvae of $H$. hampei in the interior of the fruit when applied on its surface. The insecticide cyantraniliprole affected the viability but did not affect the infectivity of $S$. feltiae and Heterorhabditis sp. (IBCB-n 46).

\section{References}

ALLARD, G. B.; MOORE, D. Heterorhabditis spp. nematodes as control agents for coffee berry borer Hypothenemus hampei (Scolytidae). Journal of Invertebrate Pathology, New York, v. 54, n. 1, p. 45-48,
1989.

ALMENARA, D. P.; ROSSI, C.; NEVES, C. M. R.; WINTER, C. E. Nematoides entomopatogênicos. In: SILVANETO, M.A. C. da; WINTER, C.; TERMIGNONI, C. (Ed.). Tópicos avançados em entomologia molecular. Rio de Janeiro: INCT-EM, 2012. p. 1-40.

ALVES, V. S.; MOINO, J. A.; SANTA-CECILIA, L. V. C.; ANDALÓ, V.; SOUZA, G. C. Patogenicidade de nematoides entomopatogênicos a cochonilha-da-raizdo-cafeeiro Dysmicoccus texensis (Tinsley) (Hemiptera: Pseudococcidae) em laboratório. Arquivos do Instituto Biológico, São Paulo, v. 76, n. 1, p. 67-73, 2009.

ANDALÓ, V.; MOINO JÚNIOR, A.; SANTACECILIA, L. V. C. Compatibilidade de nematoides entomopatogênicos com produtos fitossanitários utilizados na cultura do cafeeiro. Nematologia Brasileira, Piracicaba, v. 28, n. 2, p. 149-158, 2004.

BENAVIDES-MACHADO, P.; QUINTERO, J. C.; LÓPEZ, J. C. Evaluación en el laboratorio de nematodos entomopatógenos nativos para el control de la broca del café. Cenicafé, Caldas, v. 61, n. 2, p. 119-131, 2010.

BORTOLUZZI, L.; ALVES, L. F. A.; ALVES, V. S.; HOLZ, N. Entomopathogenic nematodes and their interaction with chemical insecticide aiming at the control of banana weevil borer, Cosmopolites Sordidus Germar (Coleoptera: Curculionidae). Arquivos do Instituto Biológico, São Paulo, v. 80, n. 2, p. 183-192, 2013.

CASTILLO, A.; MARBÁN-MENDOZA, N. Evaluación em laboratorio de nematodos Steinernematidos y Heterorhabditidos para el control biológico de la broca del café, Hypothenemus hampei Fer. Nematropica, Flórida, v. 26, n. 2, p. 101-109, 1996.

DUNCAN, L. W.; DUNN, D. C.; BAGUE, G.; NGUYEN, K. Competition between entomopathogenic and free-living bactivorous nematodes in larvae of the weevil Diaprepes abbreviatus. Journal of Nematology, Loudonville, v. 35, n. 2, p. 187-193, 2003.

FERREIRA, D. F. SISVAR: a computer statistical analysis system. Ciência e Agrotecnologia, Lavras, v. 35, n. 6, p. 1039-1042, 2011.

GAUGLER, R.; WANG, Y.; CAMPBELL, J. F. Aggressive and evasive behaviors in Popillia japonica (Coleoptera: Scarabaeidae) larvae: defences against entomopathogenic nematode attack. Journal Invertebrate Pathology, New York, v. 64, n. 3, p. 193-199, 1994.

GEDEN, C. J.; AXTELL, R. C.; BROOKS, W. M. Susceptibility of the lesser mealworm, Alphitobius diaperinus (Coleoptera: Tenebrionidae) to the entomogenous nematodes Steinernema feltiae, S. glaseri 
(Steinernematidae) and Heterorhabditis heliothidis (Heterorhabditidae). Journal of Entomological Science, Athens, v. 20, n. 3, p. 331-339, 1985.

GIOMETTI, F. H. C.; LEITE, L. G.; TAVARES, F. M.; SCHMIT, F. S.; BATISTA FILHO, A.; DELL'ACQUA, R. Virulência de nematoides entomopatogênicos (Nematoda: Rhabditida) a Sphenophorus levis (Coleoptera: Curculionidae). Bragantia, Campinas, v. 70, n. 1, p. 81-86, 2011.

JARAMILLO, J.; MUCHUGU, E.; VEGA, F. E.; DAVIS, A.; BORGEMEISTER, C.; CHABI-OLAYE, A. Some like it hot: the influence and implications of climate change on coffee berry borer (Hypothenemus hampei) and coffee production in East Africa. PLoS One, San Francisco, v. 6, n. 9, p. 1-14, 2011.

KOPPENHÖFER, A. M.; FUZY, E. M. Effect of the anthranilic diamide insecticide, chlorantraniliprole, on Heterorhabditis bacteriophora (Rhabditida: Heterorhabditidae) efficacy against white grubs (Coleoptera: Scarabaeidae). Biological Control, San Diego, v. 45, n. 1, p. 93-102, 2008.

LARA, J. C.; LÓPEZ, J. C.; BUSTILLO, A. E. Efecto de entomonematodos sobre poblaciones de la broca del café, Hypothenemus hampei (Coleoptera: Scolytidae), en frutos en el suelo. Revista Colombiana de Entomología, Bogota, v. 30, n. 2, p. 179-185, 2004.

LAZNIK, Z.; VIDRIH, M.; TRDAN, S. The effects of different fungicides on the viability of entomopathogenic nematodes Steinernema feltiae (Filipjev), S. carpocapsae Weiser, and Heterorhabditis downesi Stock, Griffin \& Burnell (Nematoda: Rhabditida) under laboratory conditions. Chilean Journal of Agricultural Research, Chillán, v. 72, n. 1, p. 62-67, 2012.

LEWIS, E. D.; CAMPBELL, J.; GRIFFIN, C.; KAYA, H.; PETERS, A. Behavioral ecology of entomopathogenic nematodes. Biological Control, San Diego, v. 38, n. 1, p. 66-79, 2006.

MANTON, J. L.; HOLLINGSWORTH, R. G.; CABOS, R. Y. M. Potential of Steinernema carpocapsae (Rhabditida: Steinernematidae) against Hypothenemus hampei (Coleoptera: Curculionidae) in Hawaii. Florida Entomologist, Gainesville, v. 95, n. 4, p. 1194-1197, 2012.

MOLINA, J. P. A.; LÓPEZ, N. J. C. Efeito da aplicação de nematoides entomopatogênicos sobre frutos infestados com broca-do-café, Hypothenemus hampei (Coleoptera: Scolytidae). Nematologia Brasileira, Piracicaba, v. 33, n. 2, p. 115-122, 2009.

Producción in vivo de três entomonematodos con dos sistemas de infección en dos hospedantes.
Revista Colombiana de Entomología, Bogotá, v. 27, n. 1-2, p. 73-78, 2001.

Supervivencia y parasitismo de nematodos entomopatógenos para el control de Hypothenemus hampei (Coleoptera: Curculionidae) en frutos de café. Boletín de Sanidad Vegetal de Plaga, Madrid, v. 29, n. 1, p. 523-533, 2003.

MOTA, L. H. C.; SILVA, W. D.; SERMARINI, R. A.; DEMÉTRIO, C. G. B.; BENTO, J. M. S.; DELALIBERA, I. Autoinoculation trap for management of Hypothenemus hampei (Ferrari) with Beauveria bassiana (Bals.) in coffee crops. Biological Control, San Diego, v. 111, n. 1, p. 32-39, 2017.

NEGRISOLI JÚNIOR, A. S.; BARBOSA, C. R. C.; MOINO JÚNIOR, A. Avaliação da compatibilidade de produtos fitossanitários com nematoides entomopatogênicos (Rhabditida: Steinernematidae, Heterorhabditidae) utilizando o protocolo modificado da IOBC/WPRS. Nematologia Brasileira, Piracicaba, v. 32, n. 2, p. 111-116, 2008.

NEVES, P. M. O. J.; HIROSE, E. Seleção de isolados de Beauveria bassiana para o controle biológico da brocado-café, Hypothenemus hampei (Ferrari) (Coleoptera: Scolytidae). Neotropical Entomology, Londrina, v. 34, n. 3, p. 77-82, 2005.

OLIVEIRA, C. M.; AUAD, A. M.; MENDES, S. M.; FRIZZAS, M. R. Economic impact of exotic insect pests in Brazilian agriculture. Journal of Applied Entomology, Berlin, v. 137, n. 1-2, p. 1-15, 2013.

ROVESTI, L.; DESEÖ, K. V. Compatibility of chemical pesticides with the entomopathogenic nematodes, Steinernema carpocapsae Weiser and S. feltiae Filipjev (Nematoda: Steinernematidae). Nematológica, Leiden, v. 36, n. 1, p. 237-245, 1990.

SELVAN, S.; CAMPBELL, J. F.; GAUGLER, R. Density-dependent effects on entomopathogenic nematodes (Heterorhabditidae and Steinernematidae) within an insect host. Journal of Invertebrate Pathology, New York, v. 62, n. 3, p. 278-284, 1993.

SEPÚLVEDA-CANO, P. A.; LOPEZ-NUNEZ, J. C.; SOTO-GIRALDO, A. Effect of two enthomopathogenic nematodes on Cosmopolites sordidus (Coleoptera: Dryphthoridae). Revista Colombiana de Entomologia, Bogotá, v. 34, n. 1, p. 62-67, 2008.

SHAPIRO-ILAN, D. I.; GARDNER, W. A.; FUXA, J. R.; WOOD, B. W.; NGUYEN, K. B.; ADAMS, B. J.; HALL, M. J. Survey of entomopathogenic nematodes and fungi endemic to pecan orchards of the Southeastern United States and their virulence to the pecan weevil (Coleoptera: Curculionidae). Environmental Entomology, Lanham, v. 
32, n. 1, p. 187-195, 2003.

SHAPIRO-ILAN, D. I.; MCCOY, C. W.; FARES, A.; OBREZA, T.; DOU, H. Effects of soil type on virulence and persistence of entomopathogenic nematodes in relation to control of Diaprepes abbreviatus. Environmental Entomology, Lanham, v. 29, n. 5, p. 1083$1087,2000$.

STUART, R. J.; SHAPIRO-ILAN, D. I.; JAMES, R. R.; NGUYEN, K. B.; McCOY, C. W. Virulence of new and mixed strains of the entomopathogenic nematode Steinernema riobrave to larvae of the citrus root weevil Diaprepes abbreviatus. Biological Control, San Diego, v. 30, n. 2, p. 439-445, 2004.

TAVARES, F. M.; BATISTA FILHO, A.; LEITE, L. G.; ALMEIDA, L. C.; SILVA, A. C.; AMBROS, C. M. G. Efeito de Heterorhabditis indica e Steinernema sp. (Nemata: Rhabditida) sobre larvas do bicudo da cana-deaçúcar, Sphenophorus levis (Coleoptera: Curculionidae), em laboratório e casa-de-vegetação. Nematologia Brasileira, Piracicaba, v. 31, n. 1, p. 12-19, 2007.

VAINIO, A. Guideline for laboratory testing of the side-effects of pesticides on entomophagous nematodes Steinernema spp. IOBC / WPRS Bulletin, Catalonia, v. 15, n. 3, p. 145-147, 1992.
VEGA, F. E.; INFANTE, F.; CASTILlO, A.; JARAMILLO, J. The coffee berry borer, Hypothenemus hampei (Ferrari) (Coleoptera: Curculionidae): a short review, with recent findings and future research directions (en línea). Terrestrial Arthropod Reviews, Washington, v. 2, n. 2, p. 129-147, 2009.

VEGA, F. E.; SIMPKINS, A.; BAUCHAN, G.; INFANTE, F.; KRAMER, M.; LAND, M. F. On the eyes of male coffee berry borers as rudimentary organs. PLoS One, San Francisco, v. 9, n. 1, p. 1-7, 2014.

VILLACORTA, A.; BARRERA J. F. Nova dieta merídica para criação de Hypothenemus hampei (Ferrari, 1867). Anais da Sociedade Entomológica do Brasil, Jaboticabal, v. 22, n. 2, p. 405-409, 1993.

VOSS, M. Nematoides entomopatogênicos (NEPs) como agentes de controle biológico de insetos. In: Manual de técnicas laboratoriais para obtenção, manutenção e caracterização de nematoides entomopatogênicos. Passo Fundo: Embrapa Trigo, 2009. p. 9-17. (Documentos Online, 119).

ZORZETTI, J.; NEVES, P. M. O. J.; CONSTANSKI, K. C.; SANTORO, P. H.; FONSECA, I. C. B. Extratos vegetais sobre Hypothenemus hampei (Coleoptera: Curculionidae) e Beauveria bassiana. Semina: Ciências Agrárias, Londrina, v. 33, n. 1, p. 2849-2861, 2012. 
